\title{
Slovo úvodem
}

\section{MUDr. Andrea Petrovičová \\ Neurologická klinika FN Nitra}

Vážené kolegyne a kolegovia,

Napísat úvodné slovo do odborného časopisu nie je nič jednoduché. Denne sme zvyknutí pracovat’ s „tvrdými a suchými“ faktami a kreativita v klasickom ponímaní sa stáva abstraktným pojmom. Spojenie vysokej odbornosti s publicistickým darom býva skôr výnimočné. Ako mladá lekárka som si kedysi kúpila útlu knižočku Neuroeseje od profesora Ivana Rektora. Jej súčastou sú aj kreatívne, inšpirujúce editoriály koncipované s d’alekým presahom čisto odborného rozmeru, ku ktorým sa rada vraciam. V súvislosti s koncepciou predkladaného čísla musím spomenút publicistický a pedagogický šarm profesora Petra Kukumberga, predsedu Sekcie pre bolest' hlavy pri Slovenskej lekárskej spoločnosti. Obe osobnosti česko-slovenskej neurológie sú navyše personifikáciou pracovnej vášne v symbióze s ludskou noblesou.

Aktuálne číslo venované bolesti hlavy dostávate do rúk v období revitalizácie pozornosti k tejto patologickej jednotke.
Ked'sa v roku 1991 v Európe stal dostupným prototyp triptanov sumatriptan a prelomila sa takmer polstoročná história ergotamínu ako prvej špecifickej substancie na liečbu migrenózneho záchvatu, vyvolalo to eufóriu medzi odborníkmi aj pacientmi. Počiatočné nadšenie vystriedalo vytriezvenie, ked'že sa počas takmer 30 rokov skúseností s triptanmi identifikovali d’alšie problémy v liečbe migrény, ako je nedostatočná odpoved' na účinné molekuly, nežiaduce účinky, možnost' vzniku tolerancie a nakoniec aj rozpaky $\vee$ preventívnej liečbe. V súčasnosti sme opät’ svedkami skutočného resp. potenciálneho nástupu nových molekúl určených na zvládnutie akútneho migrenózneho záchvatu aj prevenciu (ditany, gepanty, monoklonálne CGRP protilátky). Nasadenie úzko špecifikovanej liečby na receptorovej úrovni si vyžaduje vysokú erudíciu a skúsenosti v diagnostike bolestí hlavy, čo nie je vždy jednoduché. Symptómy primárnych bolestí hlavy sa často prekrývajú, nešpecifické symptómy migrény sa môžu zamieňat’ za iné ochorenia ( chameleons ), do toho vstupujú organické, štrukturálne ochorenia napodobňujúce migrénu ( mimics). Vymenovaná plejáda je korunovaná frekventovanou psychiatrickou komorbiditou a psychologickou'nadstavbou.

V tejto situácii výber príspevkov motivovala snaha predložit v prehliadových článkoch často $\checkmark$ praxi pertraktované problémy ako postupovat’ v ošetrení pacientov s bolestou hlavy na ambulanciách urgentnej medicíny, ako diferencovat' bolesti pri vaskulárnych ochoreniach mozgu a migréne a aké sú dostupné neurointervenčné možnosti pri zlyhaní farmakologickej liečby.

Vážení čitatelia, želám Vám napriek stále sa zvyšujúcej pracovnej náročnosti neutíchajúci entuziazmus, dostatok hlbokej empatie k našim pacientom a prekrásne posledné dni neskorého leta. 